\title{
The Role of Mercian Kings in the Founding of Minsters in the Kingdom of the Hwicce
}

\author{
Steven Bassett
}

A number of Mercian royal grants made in the late 7 th and 8th centuries have been widely interpreted as founding the Hwiccian minsters to which they relate. ${ }^{1}$ In each case the Mercian king who issued the charter has been seen as the donor of the lands from which the community of the newly established minster was meant to draw its livelihood. An example of such a charter is the one issued by the Mercian king Æthelbald in respect of Wootton Wawen (Warwicks.). The original manuscript has not survived, but there is an apparently reliable copy in the earliest of Worcester's nth-century cartularies. ${ }^{2}$ The charter was issued at an unknown date between Æthelbald's accession in 716 and the death in 737 of Uuor (Aldwine), bishop of Lichfield, who witnessed the charter. ${ }^{3}$ Although it cannot be dated more narrowly, it probably belongs to the latest years of this date range, given that it has a number of distinctive features in common with Æthelbald's charter of 736 concerning land in Usmere near Kidderminster (Worcs.) and at an unidentified place nearby named Brochyl. This latter charter survives as an original single-sheet manuscript. ${ }^{4}$ One of the distinctive features shared by this pair of charters is the make-up of their witness lists; another one is that, unusually, neither has either an invocation or a proem. The Wootton Wawen charter states that:

1 It gives me much pleasure to contribute to a volume for Barbara Yorke, whose publications have greatly inspired me and who has been a kind and generous friend for many years.

2 S 94; BL, Cotton Tiberius A. xiii, fol. 103r-v. For an important discussion of Æthelbald's charters in respect of land in the kingdoms of the Hwicce and Magonsæte (which, however, reaches a different conclusion from this chapter's), see Anton Scharer, Die angelsächsische Königsurkunde im 7. and 8. Jahrhundert (Vienna, 1982), passim but especially pp. 159-211.

3 Handbook of British Chronology, ed. E.B. Fryde, D.E. Greenway, S. Porter and I. Roy, 3rd ed. (London, 1986), p. 218.

4 S 89; Margaret Gelling, "Stour in Ismere," in Myth, Rulership, Church and Charters. Essays in Honour of Nicholas Brooks, ed. Julia Barrow and Andrew Wareham (Aldershot, 2008), pp. $83-87$. 
I, Æthelbald ... grant to my most respected and very dear associate Æthelric, son of Oshere the former king of the Hwicce, land of 20 hides, giving [it] with great goodwill of mind for ecclesiastical rule and dispensation ... So I indisputably bestow all this area ... on ... Æthelric, granting it at his request for the purpose of [establishing] monastic life. ${ }^{5}$

It has been widely assumed that in issuing this charter King Æthelbald was setting up a minster at Wootton Wawen. Æthelric is usually envisaged, more or (usually) less explicitly, as one of a number of members of the Hwiccian royalty or leading aristocrats whose job it was at various times to oversee the foundation of a minster on a Mercian king's behalf. ${ }^{6}$

We know of a number of analogous charters from the western midlands. To mention only the most reliable ones, there are three other charters issued by Æthelbald, two of which concern Hwiccian minsters. In the first one, probably issued in 718, Æthelbald granted six hides of land at Daylesford (Gloucs.) to a nun, Bægia, for constructing a minster there. ${ }^{7}$ The second is the charter by which, in 736, he booked ten hides of land at Usmere and Brochyl to a man named Cyneberht, who is addressed as associate (comes) and thegn; this, too, was for setting up a minster. ${ }^{8}$ The third of them, however, concerns Acton Beauchamp (Herefs., formerly Worcs.), which in the 8th century was in the diocese of Hereford and the kingdom of the Magonsæte. It is a grant of three hides of land, probably also made in 718 , to a thegn called Buca (who is unknown in

5 "Ego Æthilbalth ... reuerentissimo comiti meo mihique satis caro filio quondam Huuicciorum regis Oosheræs Æthilricæ terram uiginti cassatorum in possessionem æcclesiasticæ rationis atque regulæ ... larga mentis beniuolentia donans concedo. ... Omnem itaque hunc agrum ... ita nimirum præfato comiti meo Æthilricæ in jus monasticæ rationis rogatus ab eo tradens largior ..." W. de G. Birch, Cartularium Saxonicum, 3 vols (London, 1885-93), 1:227-28 (no. 157).

6 This agency is implied in, for example, H.P.R. Finberg, "The Princes of the Hwicce," in The Early Charters of the West Midlands, ed. H.P.R. Finberg, 2nd ed. (Leicester, 1972), pp. 167-80, at p. 177; Della Hooke, The Anglo-Saxon Landscape. The Kingdom of the Hwicce (Manchester, 1985), pp. 134-35; Patrick Sims-Williams, Religion and Literature in Western England, 6oo-8oo (Cambridge 1990), p. 149; D.P. Kirby, The Earliest English Kings (London, 1991), p. 12; Francesca Tinti, Sustaining Belief. The Church of Worcester from c.87o to c.110o (Farnham, 2010), pp. 194-95; and John Hunt, Warriors, Warlords and Saints. The Anglo-Saxon Kingdom of Mercia (Alcester, 2016), p. 48. On Æthelric now see Steven Bassett, "Offa, King of the East Saxons, and his West Midland Land Grants," Midland History 40 (2015), 1-23, at p. 10 and Fig. 1 on p. 9. More generally on the status of men such as Æthelric see John Blair, The Church in Anglo-Saxon Society (Oxford, 2005), p. 89 .

7 S 84 .

8 S 89 . 
any other context, as also are Bægia and Cyneberht ${ }^{9}$ ), for the perpetual support of the place's minster. ${ }^{10}$ To these four charters we can add several other similar ones issued by various Mercian kings from the 69os up to as late as the 770 s, if we are willing to include ones with a few worrying features which suggest the later improvement of what is arguably an essentially sound text."

These charters are all usually thought to represent the foundation of minsters by successive Mercian kings from Æthelred to Offa, and their recipients are seen as the king's enablers, the local agents-albeit sometimes royal ones-who implemented his wishes on the ground. However, Patrick SimsWilliams had a different view of Æthelric, Cyneberht and the others who received charters during Æthelbald's long reign. He saw them as loyal officials of Æthelbald who, on their retirement from government service, were being handed a decent leaving gift-land on which each of them would found a minster and become its abbot. ${ }^{12}$ To Sims-Williams Æthelric and the other similar recipients of Æthelbald's charters were like Bede's “thegn-abbots”. When grantees of their sort disappeared after Offa's accession in 757, he argued that, thereafter, the charters being given to laymen were nothing more than straightforward land conveyances. ${ }^{13}$ In other words, by Offa's time, although the clerks who drew up such documents were still using the standard formulaic language of earlier charters, Sims-Williams proposed that the recipients of the land which the charters said was being handed over for ecclesiastical purposes could in reality do whatever they liked with it.

But neither of these interpretations is necessarily correct. That is to say, first of all, we do not have to accept the widespread view that Mercian kings such as Æthelred and Æthelbald were themselves the founders of most of the early minsters in the kingdom of the Hwicce (and at Acton Beauchamp in the kingdom of the Magonsæte) about which we first learn from charters. Nor, secondly, do we need to agree with Sims-Williams that the landed endowments of these early minsters were given to them by a Mercian king, even if the actual

9 See the entries at <http://www.pase.ac.uk/jsp/persons/> for Bægia 1, Buca 1, and Cyneberht 3 .

$10 \mathrm{~S} 85$. At some time in the 11th century Acton Beauchamp was transferred to the diocese of Worcester and to Worcestershire: Richard Bryant with Michael Hare, Corpus of AngloSaxon Stone Sculpture. Volume X, The Western Midlands (Oxford, 2012), pp. 282-83. Also see Sims-Williams, Religion, pp. 43, 150-52.

11 For example, S 70, S 71, S 75, S 95, S 99.

12 Sims-Williams, Religion, pp. 147-54.

13 Sims-Williams, Religion, pp. 154-55; "Letter of Bede to Archbishop Egbert," in EHD 1, pp. $799-810$, at p. 806 . 


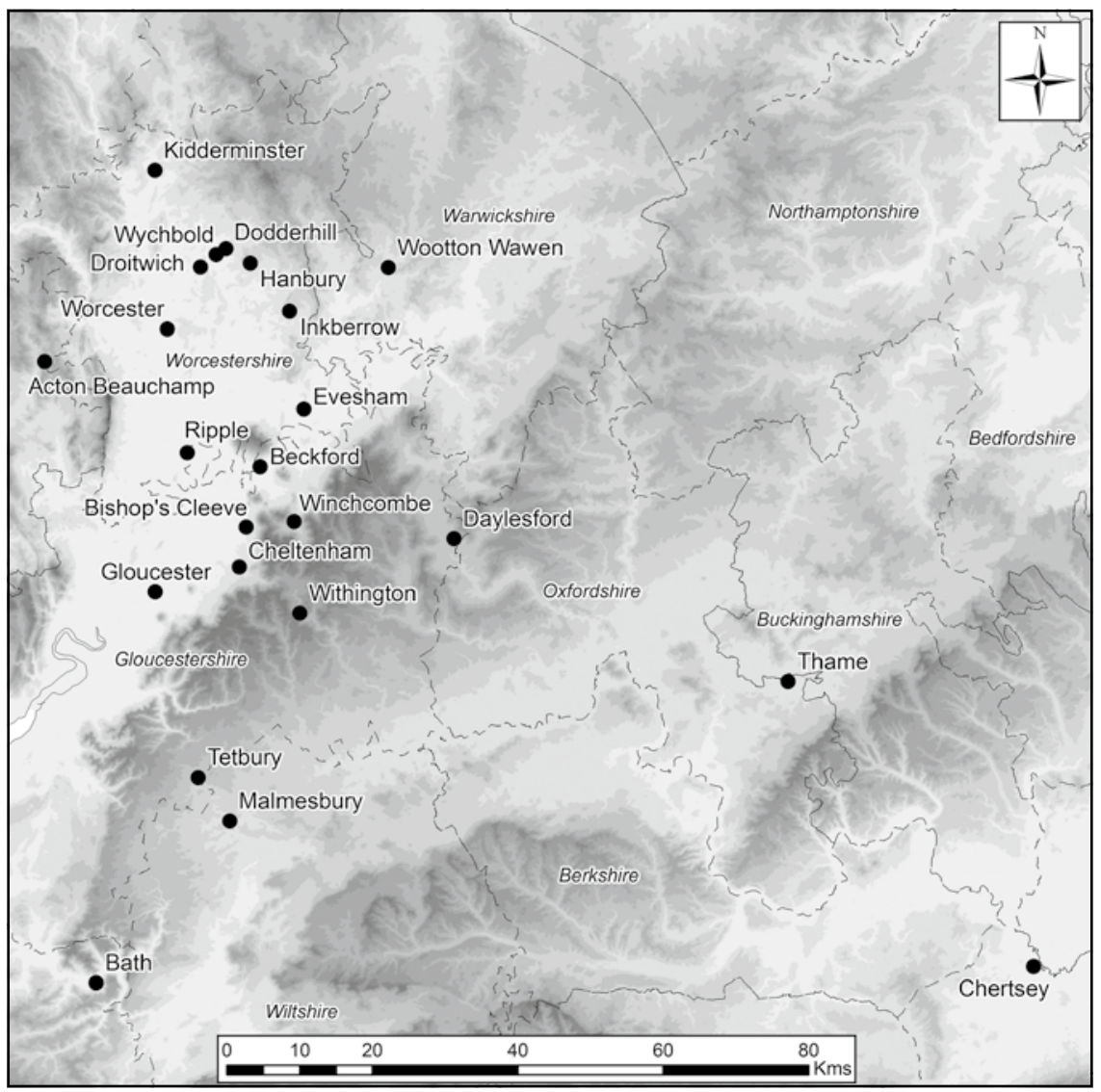

FIGURE 18.1 Places mentioned in the text

founder — and indeed the first abbot — was a retired royal official. ${ }^{14} \mathrm{~A}$ third way of making sense of these late 7 th- and 8th-century Hwiccian charters is also possible. It would require us to form a different view of the relationship being expressed in the charters between the grantor (the Mercian king) and the grantee (a man such as Æthelric). This would see the grantees as no mere Hwiccian or other functionaries of the Mercian kings, whether royal or aristocratic, active or retired. More importantly, it would identify the land which was being given to the minster concerned as the property, not of the Mercian king, but of the recipient of the charter. According to this third hypothesis, Æthelric, Cyneberht and the other grantees wanted to give land of their own to the

14 Bægia, to whom a charter was granted concerning land at Daylesford (S 84), was a woman and is therefore unlikely to have had any such role. 
minsters which they were planning to found on it, or which they had just finished founding. ${ }^{15}$

What, then, was the Mercian king's role, if he was not the minster's founder or the source of its initial landed endowment? The purpose of a charter such as Æthelric's in respect of Wootton Wawen was, I suggest, two-fold. Firstly, it signified that Æthelbald, as the grantee's overlord, was giving his permission for a substantial area of land to be taken out of the public domain and, as it were, privatized by being given to a minster. There can be little doubt that the powers of early Anglo-Saxon kings included the active supervision of the use of all land on their subjects' behalf. The arrival of the Augustinian mission in 597 posed an entirely new problem for these kings, in that each of the many minsters set up in the first century and a half of English Christianity required a substantial, and permanent, landed endowment. But this created a significant difficulty. For instance, what we know of early Northumbrian history shows that in the first flush of enthusiasm for founding and endowing minster communities, so much land was handed over to these spiritual warriors that there was not enough left to sustain the kingdom's military strength. The Mercian kings seem to have learnt from this bad example for, wherever they had overlordship, charter evidence indicates that they insisted that no land should be given to the church without their own specific royal ratification. ${ }^{16}$

Accordingly, in $672 \times 74$ we see Frithuwold, the ruler of the people of Surrey, wanting to give a large block of his own land to an existing minster at Chertsey; but before he could do so, he needed his charter to be taken to the Mercian royal residence at Thame in Oxfordshire, for inspection and ratification by his overlord Wulfhere. ${ }^{17}$ Several years later the Hwiccian king Oshere similarly had to ask Wulfhere's successor Æthelred to approve his charter in favour of the minster at Ripple (Worcs.). ${ }^{18}$ By the early 69os at the latest the extent of Æthelred's direct interference in the kingdom of the Hwicce had increased.

15 I first alluded, very briefly, to this hypothesis in Steven Bassett, "In Search of the Origins of Anglo-Saxon Kingdoms," in The Origins of Anglo-Saxon Kingdoms, ed. Steven Bassett (Leicester, 1989), pp. 3-27, at p. 18; and then at length in my review of Sims-Williams, Religion, in The Journal of Ecclesiastical History 43 (1992), pp. 300-01.

16 Nicholas Brooks, "The Development of Military Obligations in Eighth- and Ninth-Century England," in England Before the Conquest: Studies in Primary Sources Presented to Dorothy Whitelock, ed. Peter Clemoes and Kathleen Hughes (Cambridge, 1971), pp. 69-84; repr. in Nicholas Brooks, Communities and Warfare 700-1400 (London, 2000), pp. 32-47; Steven Bassett, "Divide and Rule? The Military Infrastructure of Eighth- and Ninth-Century Mercia," EME 15 (2007), 53-85; David Rollason, Northumbria, 500-110o. Creation and Destruction of a Kingdom (Cambridge, 2003), pp. 188-90.

$17 \mathrm{~S} 1165$.

18 S 52. For Oshere: Finberg, “Princes," p. 172; Bassett, “Offa," pp. 8, 10 and Fig. 1 on p. 9. 
In 692 we find the first reliable charter of several which Æthelred himself issued in respect of land in that kingdom. It concerned ten hides of land at Wychbold (Worcs.), and the charter's recipient was Oslaf, whom it described as Æthelred's former minister, i.e. royal official..$^{19}$ This land ended up in Worcester cathedral's hands, but Oslaf probably wished to be able to endow the minster at Dodderhill, which was the mother-church of the whole Droitwich area, including Wychbold itself where the ten hides of land were located. ${ }^{20}$

In such charters Æthelred stated that he was booking land for ecclesiastical use at the request of this or that Hwiccian ruler or aristocrat. ${ }^{21}$ From then on, with few exceptions, it seems that even the most senior members of the Hwiccian royal family could endow a minster only indirectly. In the Wychbold charter Æthelred said that he was booking the land "rogante me Oslauuo" ("at Oslaf's request"); and in Æthelbald's Wootton Wawen charter, as another example, the equivalent phrase is "rogatus ab eo" (literally, "having been asked by him"—i.e. by Æthelric—but, colloquially, "at his request").

It is this aspect of these charters above all else which shows that the Mercian kings were issuing them to members of the Hwiccian royal family and other aristocrats, and presumably to their peers elsewhere in England, in respect of the latter's own lands. The occurrence of the phrase "at his request" or its equivalent may be said to make this conclusion unavoidable. However, I do not wish to be thought to be ignoring the possibility that Mercian kings had land of their own in the kingdom of the Hwicce: they certainly did. Offa and Coenwulf, for instance, appear to have had Hwiccian ancestors on one side of their respective families, from whom they both presumably inherited land; and a century earlier, another Mercian king, Æthelred, may have had personal rights over land in the Avon valley as a result of his first marriage. ${ }^{22}$ But it is not land of this sort which we are considering here, nor any land which Mercian kings might have acquired in neighbouring kingdoms by other means. The charters which they issued in respect of their own land in the kingdom of

19 His name suggests that he might have been a member of the Hwiccian royal family, but he is otherwise unknown.

20 S 75; Hemingi Chartularium Ecclesiae Wigorniensis, ed. T. Hearne (Oxford 1723), p. 278; Steven Bassett, "Sitting Above the Salt: The Origins of the Borough of Droitwich," in A Commodity of Good Names: Essays in Honour of Margaret Gelling, ed. O.J. Padel and David N. Parsons (Stamford 2008), pp. 6-17.

21 On the booking of land, in particular to the Church, see Chris Wickham, Framing the Early Middle Ages: Europe and the Mediterranean 400-80o (Oxford, 2005), pp. 314-18.

22 For Offa and Coenwulf: Sims-Williams, Religion, pp. 152-53, 166-67, and references cited there; Bassett, "In Search," pp. 239-40, n. 29, and p. 241, n. 35. For Æthelred: Bassett, "Offa," p. 17. The Avon being referred to here is the Warwickshire-Worcestershire river, not the so-called Bristol Avon. 
the Hwicce are usually easy to distinguish from the ones being discussed. That is to say, they are easy to distinguish from the charters in which the grantee is a member of the Hwiccian royal family or other aristocrat (or occasionally a "servant of God" at Worcester or a nun), and in which the grantor is "asked" by the grantee to book the land in question. In all such cases this land was clearly destined for use by a minster somewhere in the diocese.

In one instance there is evidence which directly corroborates my interpretation of these Mercian royal charters. In 736 or 737 a synod chaired by Archbishop Nothhelm tackled the problem of who owned the minster at Withington (Gloucs.). The statement of the synod's decision relates that

Æthelred ... with his companion Oshere, sub-king of the Hwicce, having been asked by him, conferred into ecclesiastical right with free possession land of 20 hides ... to two nuns, Dunne and her daughter Bucga, for the construction of a minster on it for the forgiveness of his [or their] sins and strengthened this their donation with the subscription of his own hand. ${ }^{23}$

This is almost certainly a quotation taken directly from Æthelred's charter, since according to the synodal statement there were two copies of it currently available. Unfortunately, it is not a charter of which there is a surviving copy; but it was evidently one of the type being considered here, with Æthelred figuring as the grantor and Oshere, entitled sub-king of the Hwicce, as the person who wanted the land booked and who was, I contend, its actual owner. It is enough to say that the synod confirmed Dunne's granddaughter in her claim to be the minster's rightful abbess, and it allegedly stipulated that after her death the church should be placed under Worcester's direct control. ${ }^{24}$

23 “Æthelred cum comite suo subregula [sic] Huicciorum Oshere rogatus ab eo terram xx cassatorum ... duabus sanctimonialibus Dunnan videlicet et ejus filiæ Bucgan ad construendum in ea monasterium in jus ecclesiasticum sub libera potestate pro uenia facinorum suorum condonauit, propriæque manus subscriptione hanc eorum donationem firmauit." S 1429; Birch, Cartularium Saxonicum, 1:225-26 (no. 156). Both Dorothy Whitelock (EHD 1, p. 494) and Patrick Sims-Williams (Religion, p. 131) have translated pro uenia facinorum suorum as “for the forgiveness of his sins," i.e. Æthelred's, but it is possible that suorum refers to Dunne and Bucga. The English translation given here follows SimsWilliams's, with otherwise only minor alterations. For Dunne see Barbara Yorke, Nunneries and the Anglo-Saxon Royal Houses (London, 2003), pp. 34, 57.

24 I say "allegedly" since our only record of this stipulation is in a Worcester cartulary, and, if it is a copyist's interpolation, it would be only one among many suspected ones. For an incisive discussion of Worcester's manipulation of its records in the 11th century: Tinti, Sustaining Belief, chapter 3 . 
About 40 years after the synod we again hear about the Withington minster. In 774 Bishop Milred of Worcester leased its land to Abbess Æthelburg for her lifetime. In his charter, of which we have a reliable copy, he helpfully rehearsed the church's earlier history, stating that the land in question had been granted to Dunne by Oshere, sub-king of the Hwicce, with the consent of Æthelred, king of the Mercians, to be held by ecclesiastical right:

I, Milred ... humble bishop of the Hwicce, grant the land of the minster called Withington... [i.e.] 21 hides. This is the land which Oshere, subking of the Hwicce, bestowed on a handmaid of God, Dunne, so that it might be in the church's legal possession, with the consent of Æthelred, king of the Mercians. ... I willingly deliver it to the honourable Abbess Æthelburh, Ælfred's daughter. ${ }^{25}$

Here, then, we have an explicit corroboration that Oshere, not Æthelred, owned the land which the latter had booked by his now-lost charter.

I turn now to what I see as the second purpose of charters such as Æthelbald's to Æthelric concerning the minster at Wootton Wawen. It is a more specific one-indeed, it is one which in some earlier examples plainly overlaps with the purpose which has been discussed above. This second purpose was to free the grantee's land from public renders and other obligations, so that he could give it, entirely unburdened, to the community of the minster named in the charter. As with all land over which the Mercians had overlordship, this land would have been subject to burdens of a sort which we may loosely call national ones, as well, no doubt, as to other burdens of only local significance. So, if anyone wished to use some of his land to endow a minster, and thereby supply those belonging to its community with part or all of their livelihood, he would hope to divert to their benefit the full potential profits from the land concerned. But this would involve handing it over free, not only from all his own and his family's interests in it, but also from the king's. Donors would want the land's agricultural and other produce to be entirely devoted to the service of God; and for a long time their Mercian overlords, too, anticipated spiritual

25 "Ego Milredus ... humilis Huicciorum episcopus terram monasterii quod nominatur Uuidiandun ... xxi manentia, quam uidelicet terram Oshere subregulus Huicciorum Dunnan famulæ Dei ut esset juris ecclesiastici tradidit consentiente Æthelredo regi Marcionum ... Nunc ergo ... libenter Æthelburge honorabili abbatissæ filiæ Ælfredi eam trado." S 1255. Birch, Cartularium Saxonicum, 1: 305 (no. 217). Ælfred and Æthelburg were members of the Hwiccian royal family: Finberg, "Princes," p. 178. 
returns from such grants which far outweighed the earthly renders which they were willing to forego.

The earliest known reliable charter texts usually say nothing about tax impositions, or else they report that the minsters concerned were to hold the land freely. In the Wootton Wawen charter Æthelbald stated that he was granting the land "entirely freely" (licenter omnino). But within a few years of issuing this charter Æthelbald began insisting that national renders should from then on be paid from land which had been put to ecclesiastical use as much as from all other land. Consequently, the later the date of issue of the Wootton Wawen charter within the period $716-37$, the more hardly won was the privilege which Æthelric gained by it. These national renders are, of course, the trimoda necessitas - the three-fold obligation of maintaining 'burhs' (i.e. fortified settlements), of building and repairing bridges, and of contributing men for army service. ${ }^{26}$

From the middle years of the 8th century, therefore, Mercian charters typically freed the lands of minsters from all tax burdens except the three-fold obligation. One example of a reliable charter which goes even further than this is worth mentioning. It is one which was issued jointly by Offa and the Hwiccian king Ealdred in favour of the minster at Bishop's Cleeve (Gloucs.):

Wherefore I, Offa ... have pondered in my heart that, from among these earthly royal trappings of rule which I have received from the creator and bestower of all benefits, I should for my soul's relief and the gaining of heavenly wealth give something, however unworthy, to the Church for the profit of monastic liberty. Hence I and Ealdred, sub-king of the Hwicce, together grant for the Lord Almighty's sake and for the eternal health of our souls land of fifteen hides, that is, the estate called Timbingctun, to the minster community which is properly said to be at Cleeve and to the church of the blessed archangel Michael which has been founded there, giving this land freely into ecclesiastical possession. ${ }^{27}$

26 W.H. Stevenson, "Trinoda Necessitas," EHR 29 (1914), pp. 689-703, in which all references to it in Anglo-Saxon charters are listed in n. 3 on p. 689; Brooks, "Development of Military Obligations," pp. 69-84; John Baker and Stuart Brookes, Beyond the Burghal Hidage. Anglo-Saxon Civil Defence in the Viking Age (Leiden and Boston, 2013), pp. 43-44, 152-53. "Quapropter ego Offa .... [c] ogitaui in corde meo quatinus ex his sceptris regalibus mundanis regni perceptis a conditore ac largitore omnium bonorum aliquid quamuis minus dignum pro remedio animæ meæ et pro adipiscenda præmia polorum in usus monasticæ liberalitatis ecclesiis donarem. Ideoque ego et Aldredus subregulus Huicciorum in commune pro domino omnipotenti et pro eterna salute animæ nostræ terram ter quinos 
This charter can be dated to $777 \times 79$. By then the kingdom of the Hwicce had been almost wholly subsumed by the Mercians, and the latter's king had wideranging powers in it, including fiscal ones. After what has been seen in earlier charters, it should come as no surprise to find that this one's proem named Offa alone as the intending benefactor, with no mention being made of Ealdred prior to the statement of the actual grant. However, it was not Offa but the Hwiccian sub-king Ealdred who was giving this land to the church at Bishop's Cleeve - a minster which had almost certainly been founded by Ealdred's ancestors. In most respects, then, this was a purely Hwiccian affair. Offa's munificentia was not the grant of the land but the grant of it free of all secular burdens-burdens to which the charter makes no reference-at a time when almost all land in the kingdom of the Hwicce was subject to the three-fold obligation. In other words, from Ealdred the minster community at Bishop's Cleeve gained land, and from Offa it merely gained the right to hold on to the whole of whatever profit it could manage to squeeze out of the land and its occupants.

Before the wider implications of this discussion are considered, a related issue needs to be addressed. If the land given to the minsters at, for instance, Daylesford, Wootton Wawen and Withington belonged not to the Mercian grantor of the charters concerned but to the Hwiccian grantee, was a separate charter of foundation issued to each one's community? This question can be asked about most of the minsters in the diocese of Worcester. Those referred to in late 7 th- and 8th-century charters fall into three categories. There are the ones, such as the minster at Wootton Wawen, of which we know from charters which Mercian kings issued to the men who were their actual benefactors. These may look like foundation charters but, as has been argued here, they are not. Secondly, there are well established churches like Bishop's Cleeve to which additional lands or privileges were being granted, or ones like those at Withington, Cheltenham and Beckford (both Gloucs.), for instance, which are referred to only because they were the object of a dispute. ${ }^{28}$

Finally, there are one, or at the most two, Hwiccian minsters which seem at first sight to have been set up by a Mercian king acting on his own. One is

mansiones habentem, id est uicum qui nominatur Timbingctun, ad monasterium quod proprie nuncupatur æt Clife et ad ecclesiam beati Michahelis archangeli quæ inibi fundata est libenter in ecclesiasticam possessionem donantes concedimus." S 141; Birch, Cartularium Saxonicum, 1:340-42 (no. 246); Scharer, Die angelsächsische Königsurkunde, pp. 243-44. Now also see Steven Bassett, "The Anglo-Saxon minster at Bishop's Cleeve (Gloucestershire) and its lands," in Names, Texts and Landscapes in the Middle Ages. A Memorial Volume for Duncan Probert, ed. Steven Bassett and Alison J. Spedding (forthcoming). 
Winchcombe (Gloucs.), with an alleged foundation charter which purports to have been issued in 811 by King Coenwulf; but this is widely held to be a 12th-century fabrication. ${ }^{29}$ The other minster is Hanbury, which was arguably mentioned in a now-lost charter of Wulfhere. If it was authentic it may well have been a charter, given to its abbot by the first Christian Mercian overlord of the Hwicce, by which the latter confirmed the minster in its existing landed endowment. ${ }^{30}$ Accordingly, none of the authentic charters being discussed here is likely to have been a foundation charter.

There is only one church for which we have a very probably authentic charter of foundation. Issued in 693 by the Hwiccian king Oshere, the charter grants land to an Abbess Cuthswith for setting up a minster at Penintanham -almost certainly Inkberrow (Worcs.) - with Cuthswith herself as its first abbess. ${ }^{31}$ If we also look at the charters whose authenticity is in doubt, we find that for no more than three other minsters - Gloucester, Bath and perhaps Ripple - there are substantially 'improved' texts which may nonetheless embody an authentic record of their having been set up by the Hwiccian kings Osric and Oshere respectively. ${ }^{32}$ However, all three are probably much later fabrications which may reliably identify the minster's founder, but which purport to be a foundation charter which may never have existed.

In many other parts of England we may reasonably account for the dearth of foundation charters in terms of the non-survival of Anglo-Saxon sources. But occurring as it does at Worcester, the Anglo-Saxon see with the best surviving records, this dearth may, perhaps uniquely, reflect a historical reality. It may mean that very few foundation charters as such were ever issued in the kingdom of the Hwicce. That is to say, when getting a Mercian overlord's permission to divert land to ecclesiastical use was an unavoidable chore, the minster's abbot or abbess would be given a copy of the resultant charter, as Dunne was at Withington, but no other documentation would be issued; but when getting the overlord's permission was unnecessary or could be avoided, Hwiccian rulers may only rarely have issued foundation charters of their own.

However, it would be wrong to presume that there can have been few charters issued in the diocese of Worcester in the late 7 th and 8th centuries of

29 S 167.

30 Steven Bassett, "A Lost Late Seventh-Century Charter concerning Hanbury (Worcs.)," Transactions of the Worcestershire Archaeological Society, 3rd Series, 26 (2018), 107-11.

$31 \quad$ S 53 ; H.P.R. Finberg, The Early Charters of Wessex (Leicester, 1964), p. 251 (cf. Margaret Gelling, "Recent Work on Anglo-Saxon Charters," The Local Historian 13 (1978), 209-16, at p. 212); Patrick Sims-Williams, "Cuthswith, Seventh-Century Abbess of Inkberrow, near Worcester, and the Würzburg Manuscript of Jerome on Ecclesiastes," ASE 5 (1976), 1-21; Yorke, Nunneries, pp. 57-58.

Respectively, $\mathrm{S}_{70}, \mathrm{~S}_{51}, \mathrm{~S}_{52}$. 
which we are unaware. The quantity and quality of the charters which survive there should not lead us to imagine that what we lack cannot ever have existed. For instance, we occasionally read in early sources about Hwiccian charters of which we are otherwise ignorant. Moreover, some of the charters which we have as single-sheet manuscripts, and which concern lands acquired by the church of Worcester in the 8th and 9th centuries, do not figure in its cartularies. Presumably these were charters which had been superseded by later ones, and so, being seen as of no further value, were not copied into Worcester's 11thcentury cartularies. Finally, many of the early minsters known from charters are ones which came into Worcester's hands while they still had their landed endowments intact; retaining such charters was plainly in the head minster's best interests. But there were many other minsters in the diocese of which Worcester appears not to have gained control in the 8th and 9th centuries. A few of them, such as Evesham and Gloucester, preserved their charters (or at least alleged that they had); but for most of the minsters which did not come into Worcester's hands, any charters which they had may have stood very little chance of surviving. ${ }^{33}$ It would be unwise, then, to assume that most minsters in the diocese of Worcester were set up without a charter of any sort being issued.

Two sorts of conclusions may be offered. First, we are faced with the likelihood that we know rather less than we thought that we did about the circumstances in which individual minsters were set up in the diocese of Worcester, or indeed about the date of their foundation. Some of the charters referred to here may have been issued at the time at which the minsters concerned were founded, or only shortly afterwards; but others may be significantly retrospective. The latter may be ones which were acquired by a minster community whose church had been founded before Mercian kings began to require all proposed grants of land to churches to be submitted for their ratification. No Hwiccian king is mentioned in, for example, King Æthelred's surviving charter in respect of the land which the West Saxon minster at Malmesbury held at Tetbury in the neighbouring kingdom of the Hwicce. ${ }^{34}$ These charters are among the very earliest which we know of in the west midlands, and each may have been solicited by an abbot who was gravely concerned that the increasing overlordly power of the Mercian kings within the kingdom of the Hwicce threatened his church's rights over its land there. It may be no coincidence that

33 Worcester may sometimes have incorporated text from charters granted to the minster communities whose lands it took control of, producing spurious replacements which claimed that it itself had been the recipient of the grants concerned. For a probable example: Bassett, "Offa," pp. 14-16, 20.

34 S 71, which Susan Kelly reckons to be essentially acceptable: Charters of Malmesbury Abbey, ed. S.E. Kelly, Anglo-Saxon Charters 11 (Oxford, 2005), pp. 135-38. 
if we were to search for monastic churches which may already have existed before the Anglo-Saxon Church established firm control in western England, Malmesbury would arguably be among the prime candidates.

My second conclusion has wider implications. In so far as the surviving Worcester charters form a representative sample from which we may reasonably hope to generalize, we see in them a new measure of the rate of subjection of the Hwicce to Mercian control. The role of early Mercian kings in the setting up of Hwiccian minsters is significantly redefined by this focus on the implication of phrases such as "rogatus ab eo" ("at his request") and "rogante me Oslauuo" ("at Oslaf's request"), and, more broadly, on what evidence we have of whose land these minsters were gaining. This has led to the realization that the Mercian kings were not their founders, and that it was the recipients of their charters who founded the churches concerned (or whose ancestors did, in cases where they already existed). Accordingly, the extent to which the early Mercian kings personally owned land in the kingdom of the Hwicce should now be reconsidered. We need not believe that they had many large estates scattered around the kingdom, on which they set up well endowed minster communities which may have been designed to act as a Mercian fifth column, or from which they rewarded Hwiccian collaborators for faithful service.

That said, however, the reality of the Mercian kings' overlordship of the Hwicce is not called into question by this new way of looking at their charters. Rather, it reveals that the amount of direct control which the Mercians had over the Hwicce was at first far less than has frequently been assumed. Instead, we have found yet another indication that their control increased steadily with time, taking a century or more to achieve the total domination which they undoubtedly had by the end of the 8th century. It was a domination which came, moreover, not from military conquest, but from a policy of aggressive diplomacy sustained over a long period of time and backed up by the ever-real threat of military intervention. ${ }^{35}$

The obvious corollary of this is that the rulers of the Hwicce had scope for more independent action than used to be thought and that they had it for much longer. Stenton first argued in 1918 that their deteriorating status through time was expressed in their changing titles in charters in which their Mercian overlord also had a hand. ${ }^{36}$ This growing subordination was matched by that of

35 Bassett, "Divide and Rule?" pp. 54-61.

36 F.M. Stenton, "The Supremacy of the Mercian Kings," EHR 33 (1918), 433-52; reprinted in Preparatory to Anglo-Saxon England, ed. Doris Mary Stenton (Oxford, 1970), pp. 48-66. Also see Scharer, Die angelsächsische Königsurkunde, pp. 255-59; Barbara Yorke, Kings and Kingdoms of Early Anglo-Saxon England (London, 1990), pp. 108-09. 
their peers in other kingdoms, even though the quality of information which we find in Hwiccian charters far surpasses what is available for most of the other polities which succumbed to the Mercians. We also see their steadily increasing subordination in other ways, such as the broadening geographical distribution of the grants of Hwiccian land made by successive Mercian kings acting on their own. ${ }^{37}$ However, the charters of the type discussed here should not beguile us into underestimating the extent to which their own subjects thought of the rulers of the Hwicce as real kings in the late $7^{\text {th }}$ and 8th centuries.

In almost every context in which we have observed these rulers, they were going through the motions necessary to keep their Mercian overlords content. The latter's role may look like the predominant one in founding new minsters in the kingdom of the Hwicce, in adding to the lands of existing ones, and (as, arguably, with Malmesbury), in confirming them in what they already had. But appearances may be deceptive, especially when the trappings of royal majesty are concerned. An overlord could be expected to emphasize both his own overlordship and the lesser ruler's subordination - and we can see this very clearly in the charters which concern Hwiccian land. But by scraping away the Mercian veneer on the transactions which they record, we find that in most cases we are hearing about Hwiccian royal or aristocratic donations to the kingdom's minsters, not Mercian ones. Mercian kings insisted on ratifying all land transactions in the polities of those rulers who recognized their overlordship. When it pleased them to do so, they could be generous to minster communities by allowing them to hold their lands tax-free. But in most cases, and possibly in all of them, this was the limit of their generosity. The lands which these minsters held had been granted to them, not by the Mercian kings who figure so prominently in the charters, but by the local ruler or by other leading members of his polity. This enables us to see that the role of these Mercian kings in the setting up of minsters in areas over which they had overlordship was a much slighter one than it has been previously thought to have been. ${ }^{38}$

37 Bassett, "In Search," pp. 8-17.

38 An early version of this chapter was given as a paper at the University of Birmingham's Medieval History Research Seminar in January 2011. I am grateful for the discussion of it then, and respectively to Michael Hare and Sarah Wager and to Ryan Lavelle and an anonymous referee for their helpful comments on two subsequent versions. 